\title{
Metasomatic history of the lithospheric mantle beneath the Styrian Basin (W-Pannonian Basin)
}

\author{
L. E. ARADI ${ }^{1 *}$, E. BALI ${ }^{2}$, M. BERKESI ${ }^{1}$, A. ZANETTI ${ }^{3}$ AND \\ CS. SZABÓ ${ }^{1}$ \\ ${ }^{1}$ Lithosphere Fluid Research Lab, Eötvös University, \\ Hungary (*correspondance: aradi.laszloelod@ttk.elte.hu; \\ martaberkesi@caesar.elte.hu; cszabo@elte.hu) \\ ${ }^{2}$ Faculty and Institute of Earth Sciences, University of \\ Iceland (eniko@hi.is) \\ ${ }^{3}$ Istituto di Geoscienze e Georisorse, CNR, U.O.S. of Pavia, \\ Italy (zanetti@crystal.unipv.it)
}

The Styrian Basin is located at the westernmost part of the Carpathian-Pannonian region, in the transition zone between the Pannonian Basin and the Eastern Alps. Beneath the area a subducted slab is suspected and subduction related volcanic rocks are present. The lithospheric mantle beneath the Styrian Basin (SB) was sampled by Plio-Pleistocene alkali basalts, which brought mantle xenoliths to the surface.

Mantle xenoliths from the SB are mostly coarse granular, amphibole-bearing spinel lherzolites with microstructures indicating extensive annealing. Three geochemical events were recorded in the SB xenoliths. The first event, initial, ancient partial melting was followed by an old metasomatic event, which formed lithological heterogeneities (e.g. websterite, dunite) occurring as veins, bands and layers. The most recent geochemical event recorded in the SB xenoliths is the migration of a hydrous alkaline melt and its fractionated fluid, originating from a nephelinitic melt.

This melt migrated from the asthenosphere, forming melt channels in the lithospheric mantle. Close to the channels the metasomatic agent caused extensive amphibole and phlogopite formation, which contain high amount of basaltic elements (such as $\mathrm{Ti}, \mathrm{Fe}$ ), $\mathrm{K}$, light rare earth elements and incompatible trace elements such as $\mathrm{Zr}$ and $\mathrm{Hf}$. Further on, the melt enriched in volatiles (mainly $\mathrm{H}_{2} \mathrm{O}$ and $\mathrm{CO}_{2}$ ) and fluid mobile elements (e.g. $\mathrm{U}, \mathrm{Pb}, \mathrm{Cl}$ and $\mathrm{P}$ ). In these xenoliths, the residual fluids were trapped in the newly formed amphiboles. Raman microspectroscopy combined with microthermometry revealed an exceptional $\mathrm{Na}^{+}$and $\mathrm{SO}_{4}{ }^{2-}$ bearing, $\mathrm{Cl}^{-}$free fluid phase. At the distal fronts of the melt source, the metasomatic agent enriched in $\mathrm{H}_{2} \mathrm{O}$ but depleted in basaltic elements, $\mathrm{K}$ and LREE, leading to the modal decrease of amphiboles. Xenoliths showing the least amount of metasomatism, could have been traced by the formation of minor amphibole and by hydrogen enrichment in the nominally anhydrous minerals. 